\begin{tabular}{|c|ccc|}
\hline \multirow{2}{*}{$\begin{array}{c}\text { ADIYAMAN ÜNIVERSITESI SOSYAL BILIMLER ENSTITÜSÜ DERGISI } \\
\text { ISSN: 1308-9196 }\end{array}$} \\
\cline { 2 - 4 } & Yıl : 4 & Sayı : 6 & Haziran 2011 \\
\hline
\end{tabular}

\title{
KIRŞEHIR ÇEŞMELERi*
}

Lokman TAY*

Özet

\begin{abstract}
Bu çalışmada, Kırşehir il merkezindeki tarihi çeşmeler Türk sanatı açısından incelenmiştir. Çalışma kapsamında gerçekleştirilen saha araştırması ve kaynak taraması sonucunda, beşi sağlam, ikisi yıkılmış olmak üzere yedi adet tarihi çeşme tespit edilmiştir. Tamamı XVIII. ve XIX. yüzyıllara tarihlendirilen çeşmeler, mahalle çeşmesi şeklinde, tek cepheli ve tek kemerli olarak inşa edilmiştir. Günümüze ulaşan çeşmelerden dördü yuvarlak kemerli, biri ise sivri kemerlidir. Çalışmamızın amacı, Kırşehir çeşmelerini belgeleyerek bilim dünyasına tanıtmak ve çeşmelerin hem kendi içindeki gelişimini hem de Türk çeşme mimarisindeki yerini belirlemeye çalışmaktır.
\end{abstract}

Anahtar Kelimeler: Kırşehir, çeşme, mimari, taş.

\section{KIRSEHIR FOUNTAINS}

\begin{abstract}
It these studies, the historic fountains in the centre of Kirsehir were researched in terms of Turks art. As the result of a field research and the scanning of the written sources, a total of seven historic fountains, five of which are intact and two of which are ruined, have been determined in the region in question. The fountains which date back $18^{\text {th }}$ and $19^{\text {th }}$ century were built as neighbourhood fountains and one-sided and one-arched. Of the fountains surviving, while four of them are circular arched, one of them is with pointed arch. The aim of this study is to present Kirsehir fountains to the scientific world and to designate both the progress of their architecture in the course of time and their place within the Turkish architecture of fountain.
\end{abstract}

Key Words: Kirsehir, fountain, architecture, stone.

\section{GiRiş}

İç Anadolu Bölgesi'nde bulunan ve Kızılırmak yayı ile çevrili olan Kırşehir; batıda Kırıkkale ve Ankara, doğuda Nevşehir, güneyde Aksaray ve Nevşehir, kuzeyde Yozgat illeriyle komşudur.

Kırşehir, tarih boyunca birçok medeniyete ev sahipliği yapmıştır (Şahin, 2001: 481). Türklerin Anadolu'ya gelmesinden sonra da önemli bir yol güzergâhında olması sebebiyle, sürekli el değiştirmiştir (Basınoğlu, 1981: 21-22). Özellikle, Osmanlı Devleti Anadolu Türk birliğini sağlayana kadar: Eretna, Kadı Burhâneddin, Karamanoğulları ve Dulkadiroğulları'nın eline geçmiştir. XIX. yüzyıl ortalarından itibaren önemini yitiren şehir (Yılmaz, 2006: 163), yollar üstünde küçük bir durak yeri olmuş, yüzyılın sonlarına doğru ise Ankara vilayetine

\footnotetext{
* Yapıcı eleştirileriyle makalenin şekillenmesine katkı sağlayan değerli hocam Sn. Prof. Dr. Halit ÇAL'a, kitabeleri okuyan değerli hocam Sn. Prof. Dr. Kerim TÜRKMEN'e ve arazi çalışmasında beni yalnız bırakmayan arkadaşım Nazım BOY'a teşekkür ederim.

* Öğr. Gör., Erciyes Üniversitesi, Edebiyat Fakültesi, Sanat Tarihi Bölümü, Itay@erciyes.edu.tr
} 
bağlı bir sancak merkezi konumuna gelmiştir. 1924 yılında il olan şehir, 1954-1957 yılları arasında Nevşehir iline bağlı ilçe konumuna getirilirken 1957'de yeniden il statüsüne yükseltilmiştir (Yılmaz, 2006: 165).

Çalışmamızın amacı: kültürümüzün aynası, mimari geleneğimizin bu şirin ama işlevsel öğelerini belgeleyerek, hem bilim dünyasına tanıtmak, hem de çeşmelerimizin durumuna dikkat çekmektir. Bu çalışma katalog ve değerlendirme bölümünden oluşmaktadır. Katalog bölümünde ayrıntılı mimari tanımlaması yapılan çeşmeler; cephe düzenlemeleri, yapı elemanları, kitabe, malzeme ve süsleme özellikleri açısından değerlendirilmiştir.

Başbakanlık Osmanlı Arşivi'nde yapılan çalışmalarda Kırşehir'deki çeşmelerin inşa ya da onarımına dair herhangi bir belgeye ulaşılamamıştır. Ayrıca, yine Başbakanlık Osmanlı Arşivi’nde yapılan çalışmalarda Kırşehir su yolları hakkında da bilgi bulunamamıştır. Kırşehir vakfiyeleri ile ilgili çalışmalarda da çeşmelere dair bilgi tespit edilememiştir (Gündüz, 2009).

Saha çalışması ve kaynak taraması sonucunda, beşi ayakta ikisi yıkılmış olmak üzere yedi adet tarihi çeşme tespit edilmiştir. Bu çeşmeler dışında, Ali Saim Ülgen, Lale Camisi'nin karşısında, düzgün kesme taşlarla inşa edilmiş, kemerli ve üzerinde H.892/M.1486-87 tarihli kitabe bulunan bir çeşme olduğunu belirtmektedir (Ülgen, 1942: 261). Ancak günümüzde ortadan kalkmış olan çeşmenin çizim veya fotoğrafına ulaşılamamıştır. $\mathrm{Bu}$ sebeple çeşmenin mimarisi hakkında bilgi sahibi olamıyoruz. Kırşehir'deki yapılarla ilgili bugüne kadar yapılan çalışmalarda sadece yukarıda zikrettiğimiz Ali Saim Ülgen'in çalışmasında bir adet çeşmeye yer verilmiştir. Ayrıca arşiv belgelerinde de çeşmelere dair bilgi bulunmaması bizi, tespit edebildiğimiz çeşmeler üzerinden bir değerlendirme yapmaya mecbur bırakmıştır. Bu sebeple yapacağımız değerlendirme günümüze ulaşan bu çeşmelerle sınırlı olacaktır. Tarihi bilinmeyen çeşmeler, değerlendirme bölümünde karşılaştırma yoluyla tarihlendirilmiştir.

\section{KIRŞEHIR ÇEŞMELERI}

\subsection{Ahi Evren Çeşmesi:}

Eser, Ahi Evren Mahallesi'nde, Ahi Evren Zaviyesi'nin hemen kuzeyinde bulunmakta olup, zaviyeye yakınlığından dolayı bu adı almış olmalıdır. Çeşmede inşa ya da onarım kitabesi bulunmadığı için banisi ve tarihi bilinmemektedir. Ancak, yapının benzer örneklerinin yoğun olarak XIX.yy.da inşa edilmiş olmasından hareketle bu yapıyı da XIX.yY.a tarihlendirebiliriz.

Mahalle çeşmesi şeklinde, tek cepheli ve tek kemerli olarak düzenlenen yapı, halen kullanılmaktadır. Düzensiz kesme taş malzeme ile inşa edilen yapı, 2.37 m. yükseklikte, 3.55 m. genişlilikte ve 1.45 m. derinliktedir (Çizim1). Çeşme nişi $0.60 \times 2.15 \mathrm{~m}$. ölçülerinde olup, üzeri yanlardaki yığma ayaklar üstüne oturan ve bilinçsiz onarımlar sonucu formu bozulmuş olan yuvarlak kemerle örtülüdür (Fotoğraf-1). Niş içerisinde bir adet dinlenme sekisi mevcuttur. 
Çeşmenin üstü düz dam şeklinde düzenlenerek saçak kısmı cepheden dışa taşırılan profilli silmelerle hareketlendirilmiştir. Oldukça sade olan yapıda süsleme unsuru olarak sadece saçaklardaki silmelerden söz edilebilir.

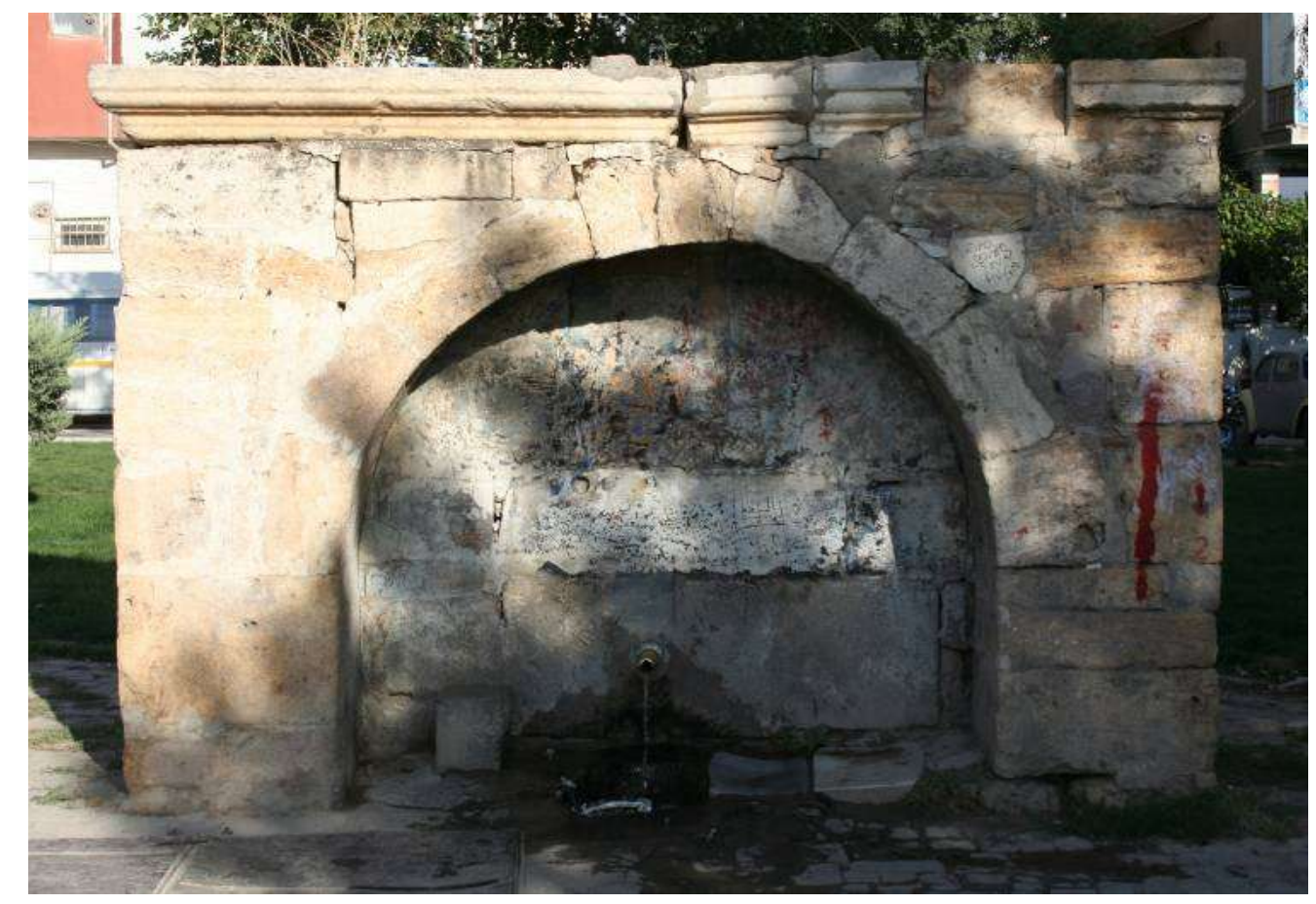

Fotoğraf-1: Ahi Evren Çeşmesi
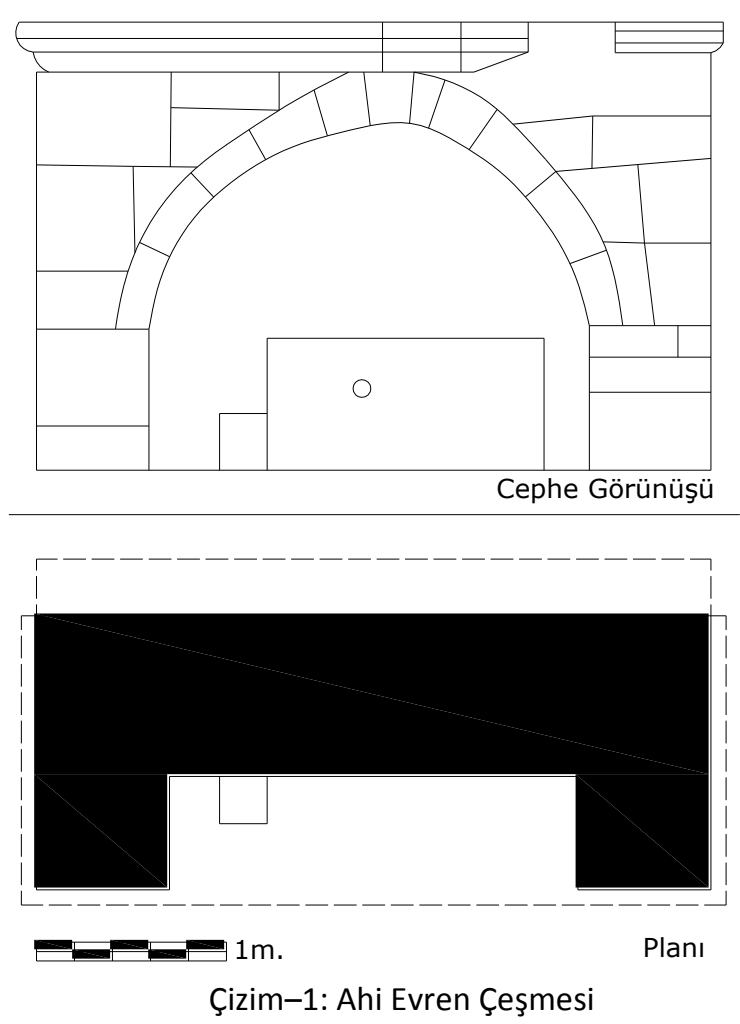


\section{2. Şeyh Kızı Hatice Çeşmesi:}

Eser, Medrese Mahallesi, Süleyman Türkmani Caddesi'nde bulunmaktadır. 2006 yılında hazırlanan Kırşehir Kültür Envanteri'nde “İmaret Çeşme” olarak geçmektedir (Güçlü, 2006: 69). Çeşmenin hemen yakınında bulunan İmaret Camisi'nden dolayı “İmaret Çeşme” adını verdikleri düşüncesindeyiz. Ancak kitabesinden çeşmeyi, Şeyh Kızı Hatice'nin yaptırdığını öğreniyoruz. Yapı, niş içerisindeki kitabesine göre H.1287/M.1870 yılında inşa edilmiştir (Fotoğraf-2). Ancak, Kırşehir Kültür Envanteri'nde, yapının 2001 yılında yıkılarak yeniden inşa edildiği belirtilmektedir (Güçlü, 2006: 69). Bakımsız durumda olan eser vatandaşlar tarafından yıkılarak yeniden yapılmış ve yıkılan çeşmenin kitabesi buraya yerleştirilmiş olmalıdır.

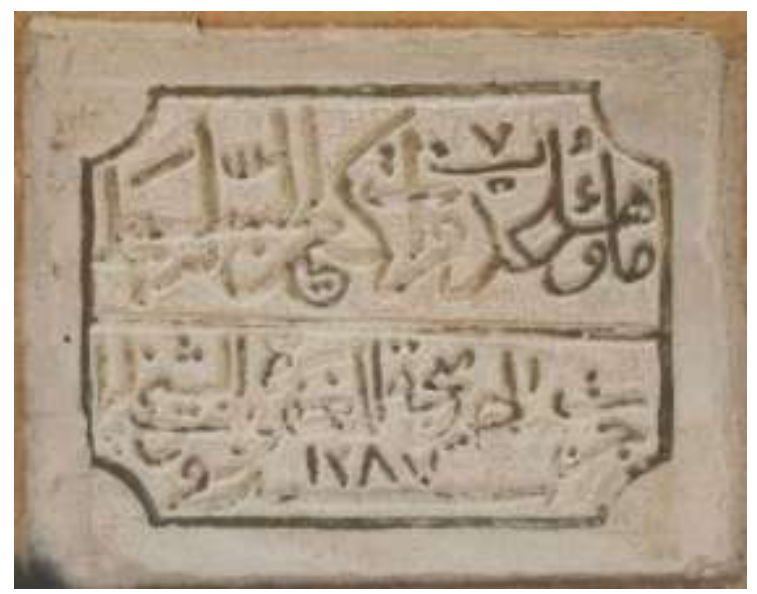

Fotoğraf-2: Şeyh Kızı Hatice Çeşmesi Kitabesi

\section{Kitabenin okunuşu:}

Ma'uha azb-u Firat ka'inü's-selsebil

Ceret? ___ Hadice El-mağfure bint-i Eş-şeyh

Kitabenin ilk satırında geçen ibare, Kur'ân-ı Kerîm'in, Furkan Sûresi, 53. âyetinin bir bölümünü teşkil etmektedir ${ }^{1}$. Ikinci satırda ise çeşmeyi yaptıran Şeyh Kızı Hatice'nin adı geçmektedir.

Mahalle çeşmesi şeklinde, tek cepheli ve tek kemerli olan yapı halen kullanılmakta olup, düzgün kesme taş malzeme ile inşa edilmiştir. Yapı, $2.22 \mathrm{~m}$. yükseklikte, $2.94 \mathrm{~m}$. genişlikte ve $1.25 \mathrm{~m}$. derinliktedir (Çizim-2). $0.55 \times 2.20 \mathrm{~m}$. ölçülerindeki çeşme nişini örten sivri kemer, aynı kotta çeşme nişini de dolaşan profilli silmelerle hareketlendirilmiş yığma ayaklar üstüne oturmaktadır (Fotoğraf-3). Niş içerisini dolaşan silme kuşağının üstünde $0.20 \times 0.16 \times 0.18 \mathrm{~m}$. ölçülerindeki bardaklık yer almaktadır.

Çeşmenin üstü düz dam şeklinde düzenlenerek saçak kısmı, cepheden dışa taşırılmış profilli silmelerle hareketlendirilmiştir. Çeşmenin batı cephesinde yapıdan $0.30 \mathrm{~m}$. dışa çıkıntı yapan ve çeşmeyle aynı malzemeden yapılmış olan çörten yer almaktadır. Sade bir şekilde inşa edilen yapıda süsleme unsuru olarak saçak kısmındaki silmelerden söz edilebilir.

\footnotetext{
1 "Birinin suyu tatlı ve susuzluğu giderici, diğerininki tuzlu ve acı iki denizi salıveren ve aralarına bir engel, aşılmaz bir sınır koyan O’dur." Kur’an-ı Kerim ve Açıklamalı Meali, Türkiye Diyanet Vakfı Yayınları, Ankara, 2007, s.363.
} 


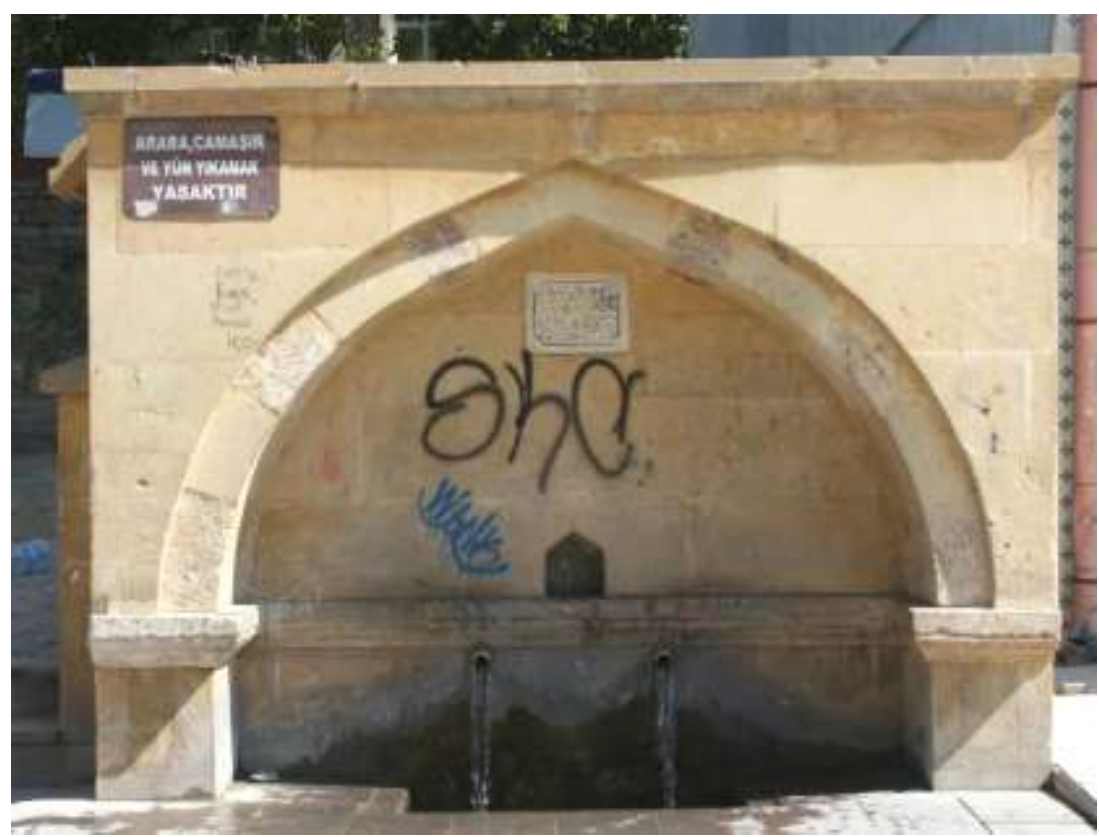

Fotoğraf-3: Şeyh Kızı Hatice Çeşmesi

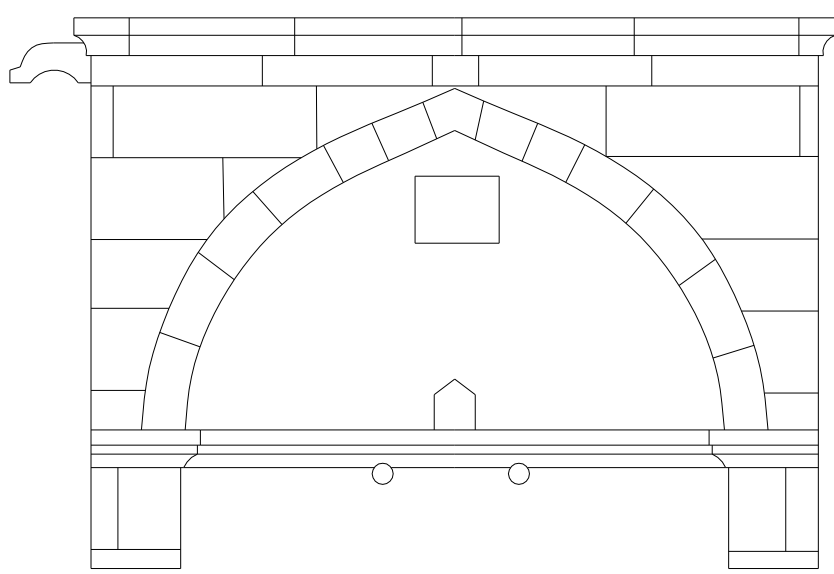

Cephe Görünüşü

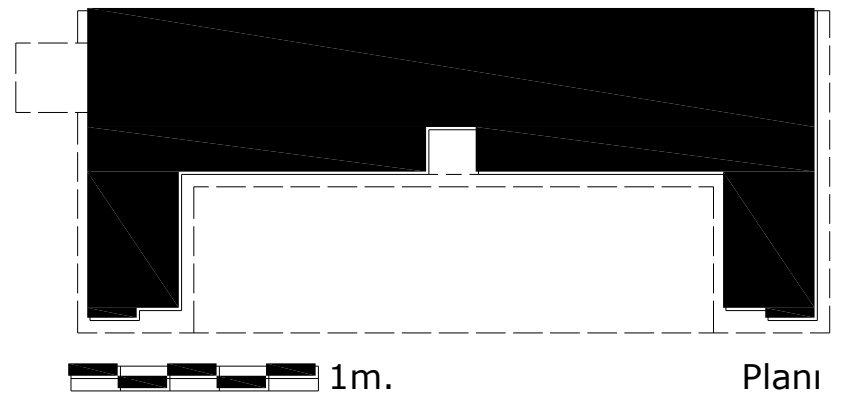

Çizim-2: Şeyh Kızı Hatice Çeşmesi 


\subsection{Tekke Çeşmesi:}

Eser, Medrese Mahallesi, 67. Sokak'ta bulunmaktadır. Çeşme nişi içerisinde, aynı zamanda aynalık taşı olarak da kullanılan kitabe tahrip olduğu için tamamı okunamamıştır (Fotoğraf-4). Bu nedenle yapının inşa tarihi ve banisi kesin olarak bilinmemektedir. Ancak, yapının benzer örneklerinin yoğun olarak XIX.yy.da inşa edilmiş olmasından hareketle bu yapıyı da XIX.yy.a tarihlendirebiliriz. Kitabenin ayna taşı olarak kullanılması, bu kitabenin başka bir yapıdan getirildiğini düşündürmektedir. Ayrıca ilk satırda geçen “imare" kelimesi çeşme kitabelerinde çok tercih edilen bir ifade değildir. Bu da kitabenin başka bir yapıdan getirildiği düşüncesini desteklemektedir. Kitabenin sağlam olan kısımlarından anlaşıldığı kadarıyla; "Allah'ın zayıf kulu Hüseyin tarafından yaptırıldı" şeklinde bir anlam çıkmaktadır.

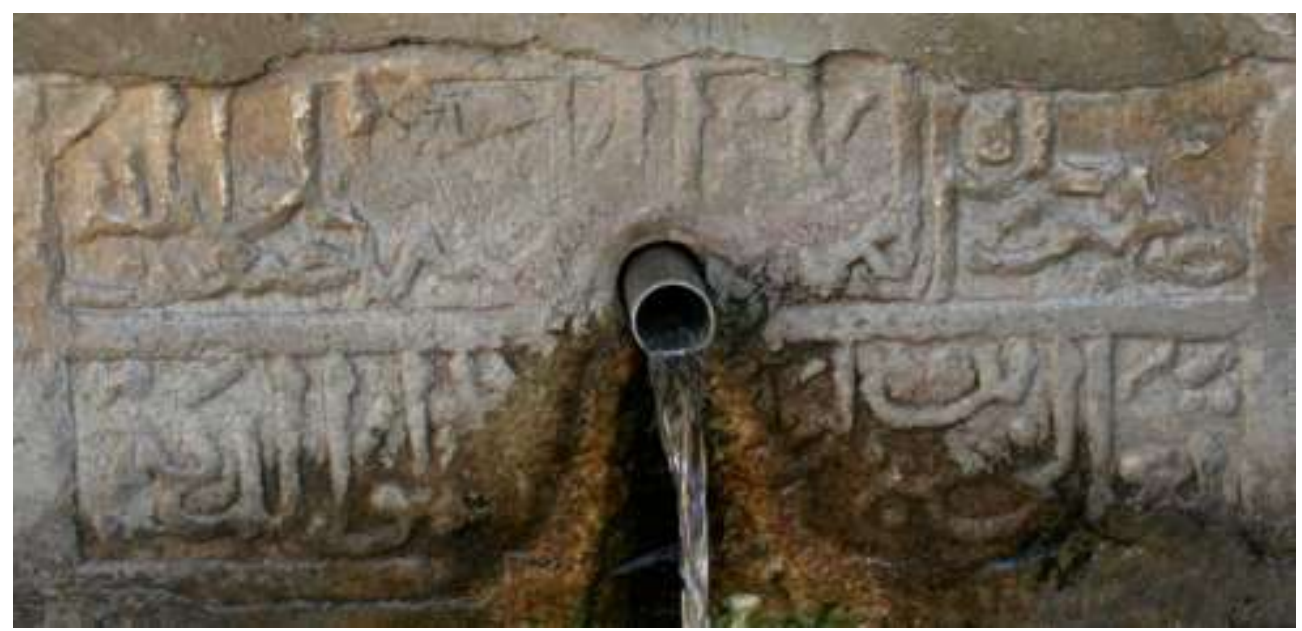

Fotoğraf-4: Tekke Çeşmesi Kitabesi
Kitabenin okunuşu:
Sahib-i hazihi'l-imare el-abd el-zaif Allah
Teali Hüseyin bin lehu velideyhi

Kitabenin anlamı:

Bu imaretin sahibi Yüce Allah'ın zayıf kulu oğlu Hüseyin

Kitabe tahrip olduğu için tam olarak okunamamıştır.

Mahalle çeşmesi şeklinde, tek cepheli ve tek kemerli olarak düzenlenen yapı, halen kullanılmakta olup, inşasında düzgün kesme taş malzeme kullanılmıştır. Çeşme, 2.26 m. yükseklikte, 3.44 m. genişlikte ve 1.40 m. derinliktedir (Çizim-3). Çeşme nişi $0.81 \times 2.22 \mathrm{~m}$. ölçülerinde olup, üzeri yanlardaki profilli silmelerle hareketlendirilmiş yığma ayaklar üstüne oturan yuvarlak kemerle örtülüdür (Fotoğraf-5). Niş içerisini dolaşan silme kuşağının üst kısmında 0.21×0.18×0.20 m. ölçülerindeki bardaklık mevcuttur.

Çeşmenin üstü, düz dam şeklinde düzenlenerek, saçak kısmı cepheden dışa taşırılmış profilli silmelerle hareketlendirilmiştir. Oldukça sade olan yapıda, süsleme unsuru olarak sadece silmelerden söz edilebilir. 


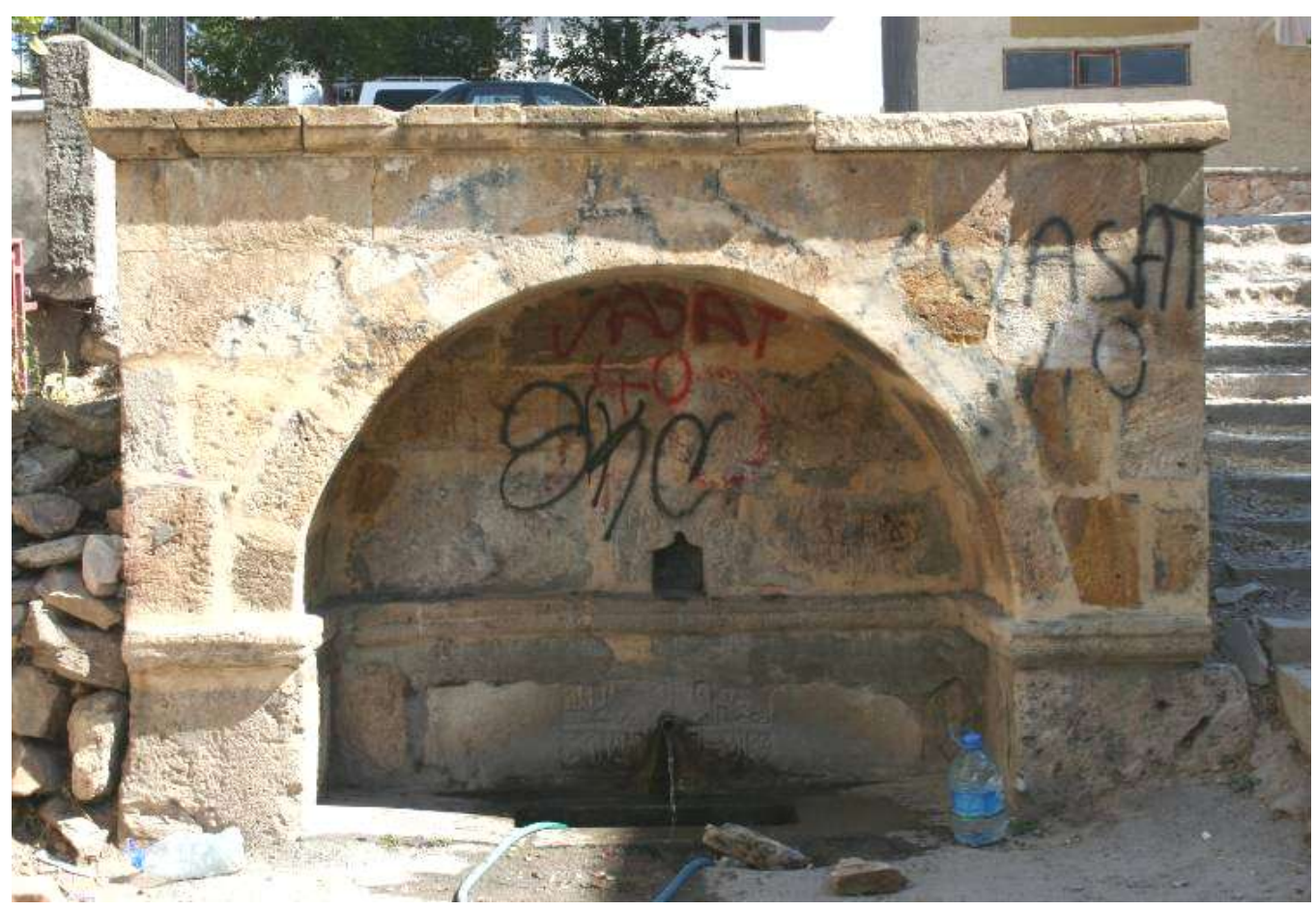

Fotoğraf-5: Tekke Çeşmesi
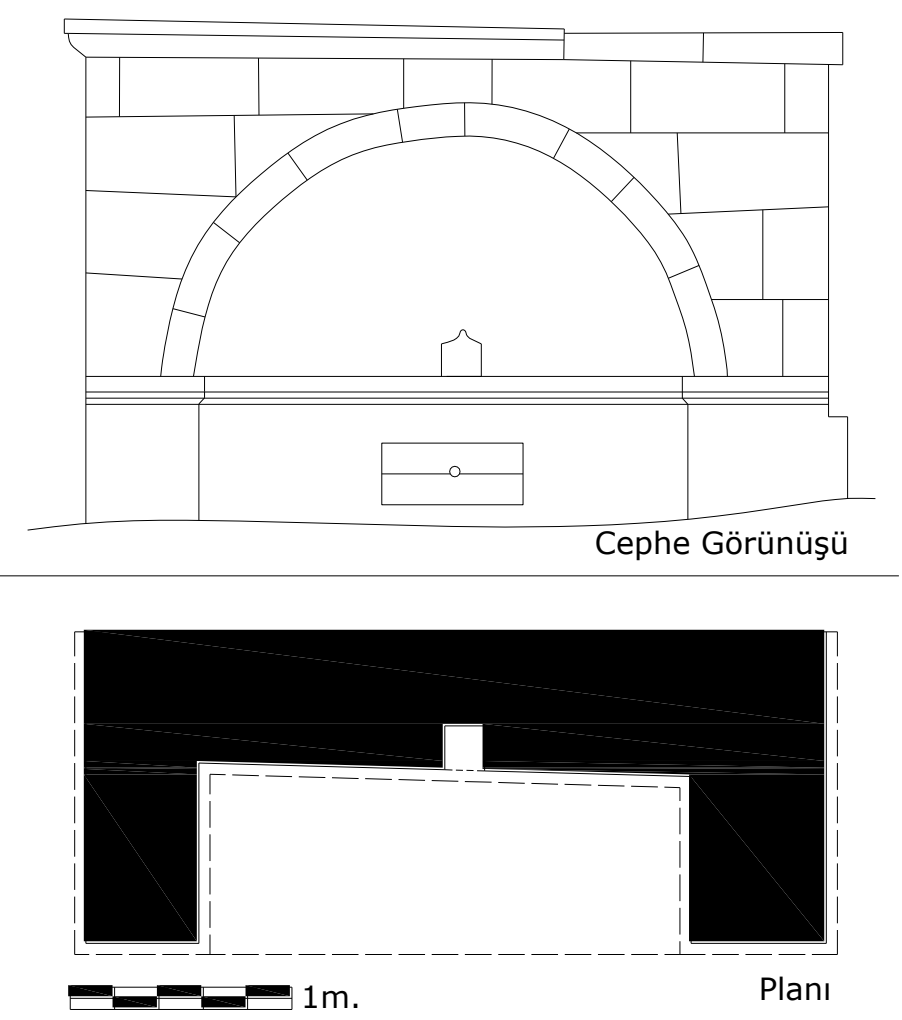

Çizim-3: Tekke Çeşmesi 


\subsection{Süleyman Ağa Çeşmesi:}

Eser, Kayabaşı Mahallesi'nde, Şehir Hamamı́nın kuzeybatısında, 335. ve 336. sokakların kesiştiği köşede bulunmaktadır. 2006 yılında hazırlanan Kırşehir Kültür Envanteri'nde "Kayabaşı Çeşmesi” olarak geçmektedir (Güçlü, 2006: 71). Muhtemelen bulunduğu mahallenin isminden dolayı bu ismi vermişlerdir. Ancak çeşmenin kitabesinde Süleyman Ağa ismi geçmektedir. Kitabe yapıdan daha kaliteli malzeme üstüne işlenmiştir. Hem kitabenin daha kaliteli malzemeye sahip olması hem de kitabenin sonunda, "yenilendi" ibaresinin kullanılması bize, yapının zaman içerisinde yıkılıp yeniden inşa edildiğini ve yıkılan çeşmenin kitabesinin burada kullanıldığını düşündürmektedir.

Yapı, niş içerisindeki kitabesine göre H.1148/M.1735-36 yılında yenilenmiştir (Fotoğraf-6).

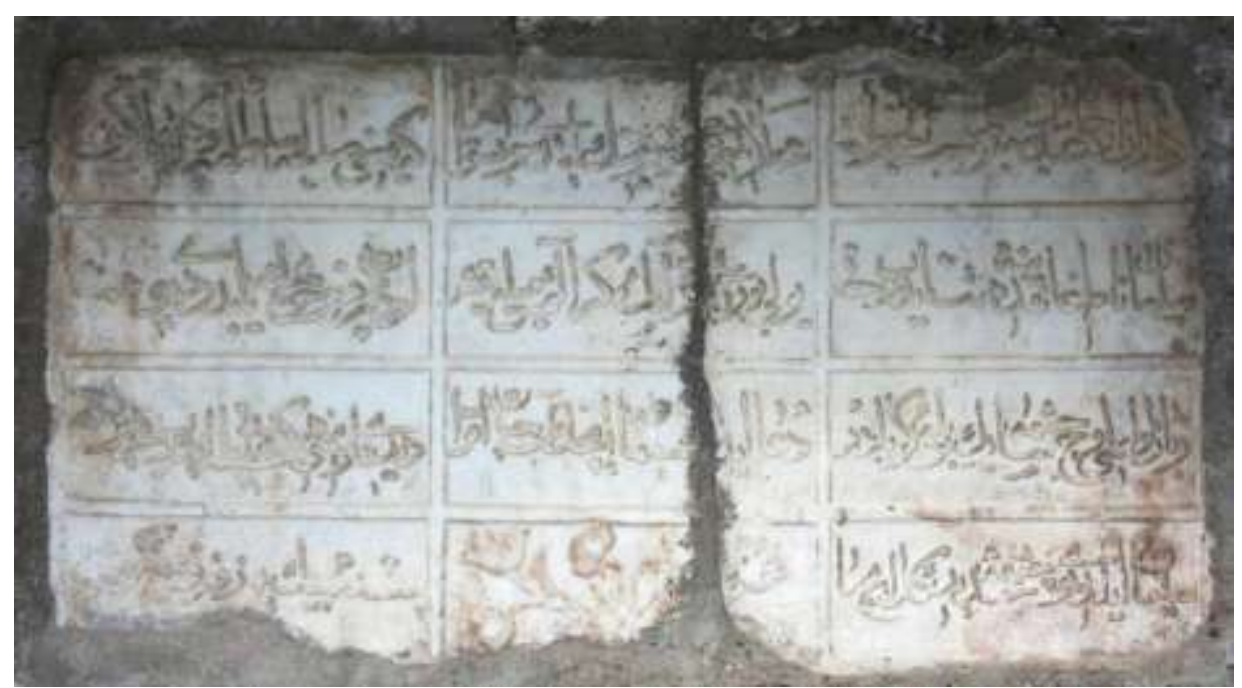

Fotoğraf-6: Süleyman Ağa Çeşmesi Kitabesi

\section{Kitabenin okunuşu:}

bir sahib'ül hayrat / Mahallesini Kırşehri'nin itdü subesu ihya / Saliha Sultan masraf kâtibi iken.

Süleyman nam-ı Ağa nakdine himmet edip Hak'ka / Yolu bura _ ve abın mekr-i altmışıyla kış / O zat perhüner Hak yoluna yaptırdı bî himmeten.

Zeban lülesi üç çeşme sarık böyle güyadır / Dua ide Süleyman'a içen ab-ı hayat ikra / Dedi tarihini hem kendi hattıyla edip tahrir

Süleyman eyledi bu çeşme-i tecdid gel iç ma / Sene bin yüz kırk sekiz.

\section{Kitabenin anlamı:}

Hayırlar sahibi Süleyman Ağa, Saliha Sultan masraf katibi iken Allah yoluna parasını harcayarak Kırşehir'in mahallesini sulara kavuşturdu. O bunu, maharetiyle Allah yoluna hizmet için yaptırdı. Bu can suyundan içenler Süleyman'a dua ede, tarihini kendi yazısıyla kaydetti. Gel iç su, Süleyman bu çeşmeyi yeniledi. Sene 1735-36. 
Mahalle çeşmesi şeklinde, tek cepheli ve tek kemerli olarak inşa edilen yapı günümüzde kullanılmamaktadır. Çeşmenin inşasında, kaba yonu taş ve çimento harcı kullanılmıştır. Çeşme, $2.00 \mathrm{~m}$. yükseklikte, $1.90 \mathrm{~m}$. genişlikte ve $1.54 \mathrm{~m}$. derinliktedir (Çizim-4). Çeşme nişi $0.48 \times 1.58 \mathrm{~m}$. ölçülerinde olup, üzerini örten formu bozulmuş yuvarlak kemer, yanlarda yer alan ayaklarla bütünlük arz eder ve zemine kadar devam eder (Fotoğraf-7).

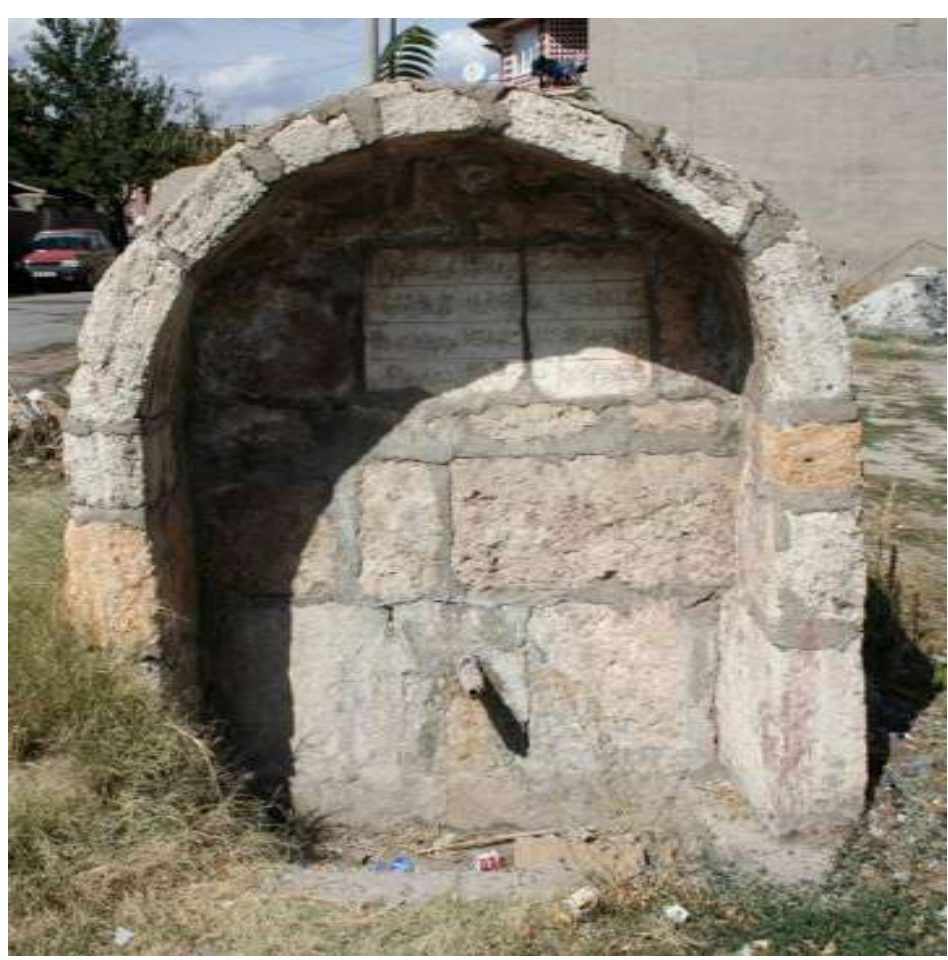

Fotoğraf-7: Süleyman Ağa Çeşmesi
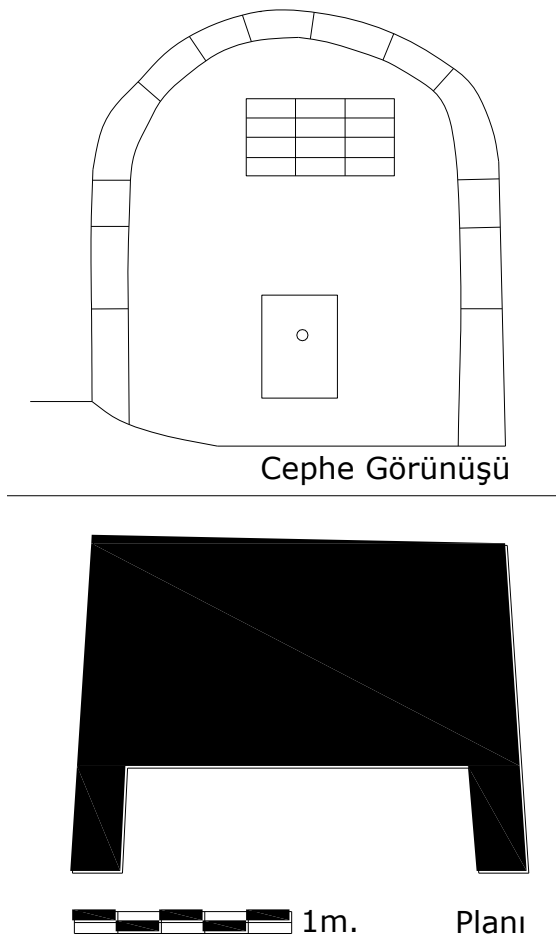

Çizim-4: Süleyman Ağa Çeşmesi

Çeşmenin üstü, ön cephede yuvarlak kemer şeklinde, arka kısımda ise düz dam olarak tasarlanmıştır. Yapıda süsleme unsuru olarak kitabe panosunun içerisine işlenmiş olan bitkisel motifleri söyleyebiliriz.

\subsection{Susuz Çeşme:}

Eser, Bağbaşı Mahallesi, Sait Kurutluoğlu Caddesi'nde 21 numaralı meskenin karşısında bulunmaktadır. Yapıda inşa ya da onarım kitabesi olmadığı için, tarihi ve banisi bilinmemektedir. Ancak, benzer örneklerinin yoğun olarak XIX.yy.da inşa edilmiş olmasından hareketle bu yapıyı da XIX.yy.a tarihlendirebiliriz.

Yapı, mahalle çeşmesi şeklinde, tek cepheli ve tek kemerli olarak inşa edilmiştir. Büyük boyutlu düzgün kesme taşlarla inşa edilen çeşme günümüzde kullanılmamaktadır. Çeşme $2.04 \mathrm{~m}$. yükseklikte, $4.44 \mathrm{~m}$. genişlikte ve 1.73 m. derinliktedir (Çizim-5). Çeşme nişi 1.11×2.84 m. ölçülerinde olup, üzeri yanlardaki yığma ayaklar üstüne oturan yuvarlak kemerle örtülüdür (Fotoğraf-8). Çeşme nişinin içerisi belirli bir seviyeye kadar toprakla dolmuştur. Bu sebeple su yalağı ve dinlenme sekisi bulunup bulunmadığı hususunda bilgi sahibi olamıyoruz. 
Çeşmenin üstü, düz dam şeklinde düzenlenerek saçak kısmı, cepheden dışa taşırılan profilli silmelerle hareketlendirilmiştir. Saçak kısmında bazı bölümler tahrip olmuştur. Oldukça sade olan yapıda süsleme unsuru olarak sadece saçaklardaki silmelerden söz edilebilir.

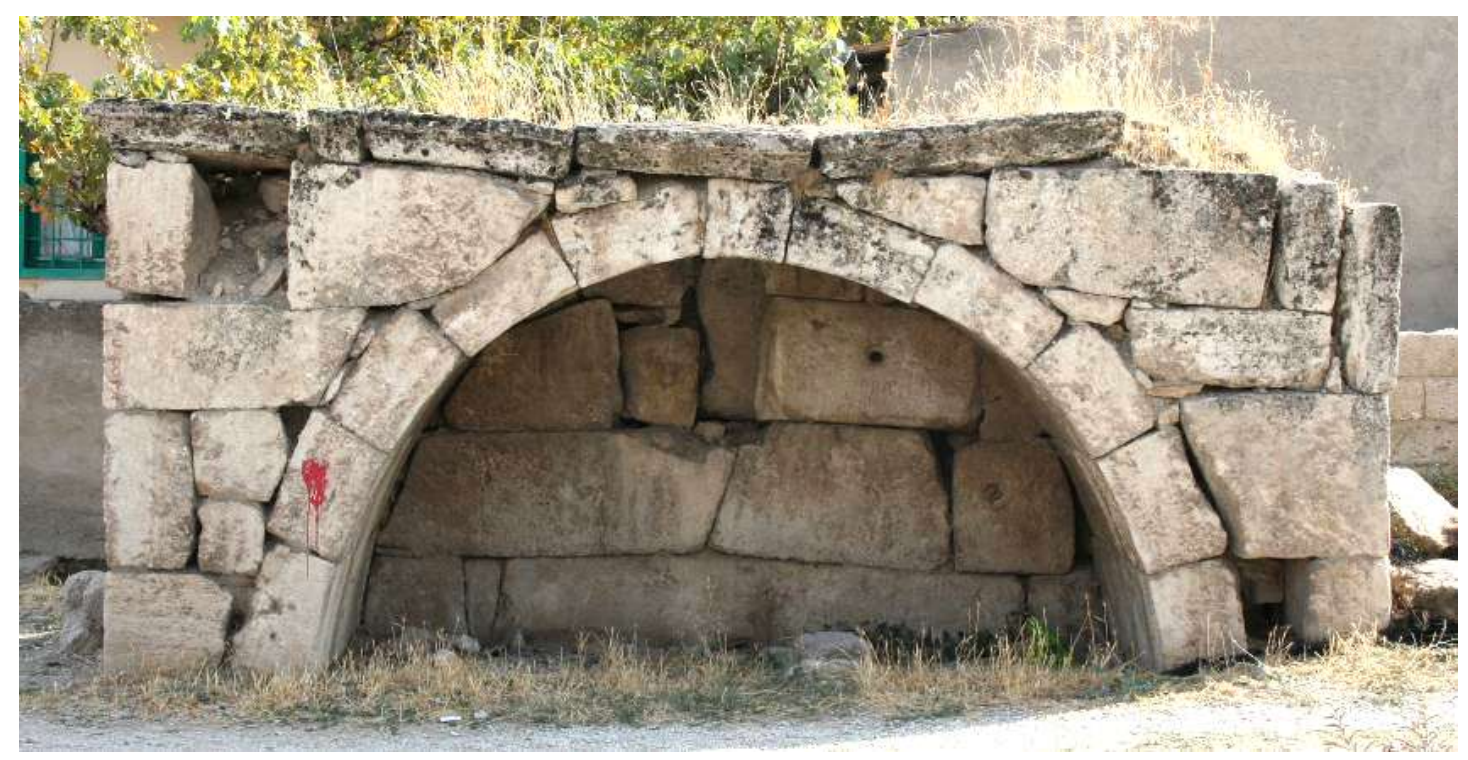

Fotoğraf-8: Susuz Çeşme
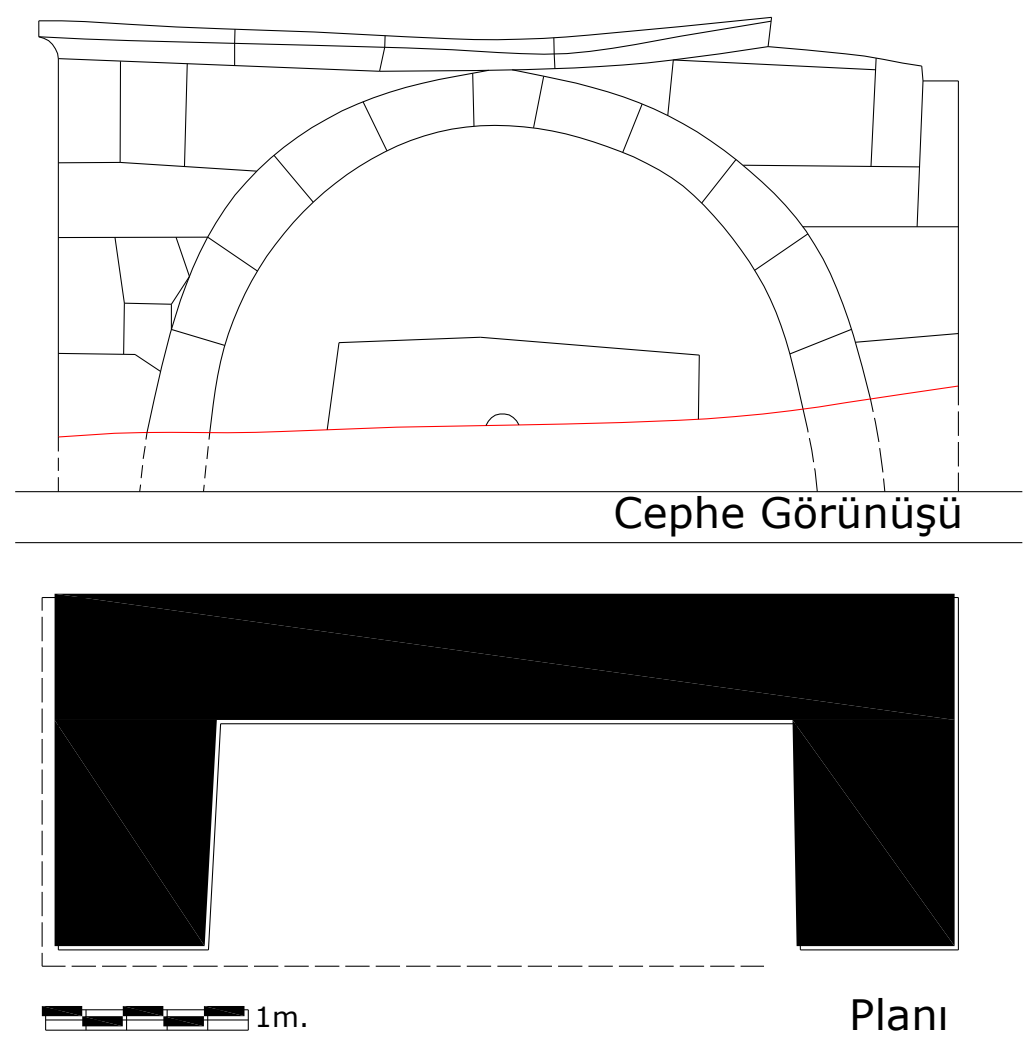

Çizim-5: Susuz Çeşme 


\subsection{Ağaların Çeşmesi:}

Eser, Kayabaşı Mahallesi, 352. Sokak'ta bulunmaktadır. Günümüzde tamamen yıkılmış olan yapının eski fotoğraflarında çeşme nişi içerisinde üç adet kitabe panosu görülmektedir. Ancak, yapı bugün ortadan kalktığı için kitabelerde ne yazdığını bilemiyoruz ${ }^{2}$. Bu sebeple çeşmenin banisi ve tarihi bilinmemektedir. Ancak yapıda üç adet kitabe bulunması, yapının çeşitli dönemlerde onarım geçirdiğini düşündürmektedir.

Günümüzde tamamen yıkılmış olan yapının eski fotoğraflarından; sivri kemerli bir kuruluşa sahip olduğu ve düzgün kesme taş malzeme ile inşa edildiği anlaşılmaktadır (Fotoğraf-9).

Çeşme nişini örten sivri kemer, aynı kotta çeşme nişini de dolaşan profilli silmelerle hareketlendirilmiş yığma ayaklar üstüne oturmaktadır. Niş içerisini dolaşan silme kuşağının üst kısmında yuvarlak kemerli bardaklık yer alır.

Eski fotoğraflarından, çeşme kemerinin kısmen, üstünün ise tamamen yıkıldığı görülmektedir. Oldukça sade olan yapıda süsleme olarak sadece silmelerden söz edilebilir.

Çeşme nişi içerisinde bulunan kitabeler okunamadığı gibi, yapı bugün tamamen ortadan kalktığı için tarihlendirilmesi de mümkün olmamıştır.

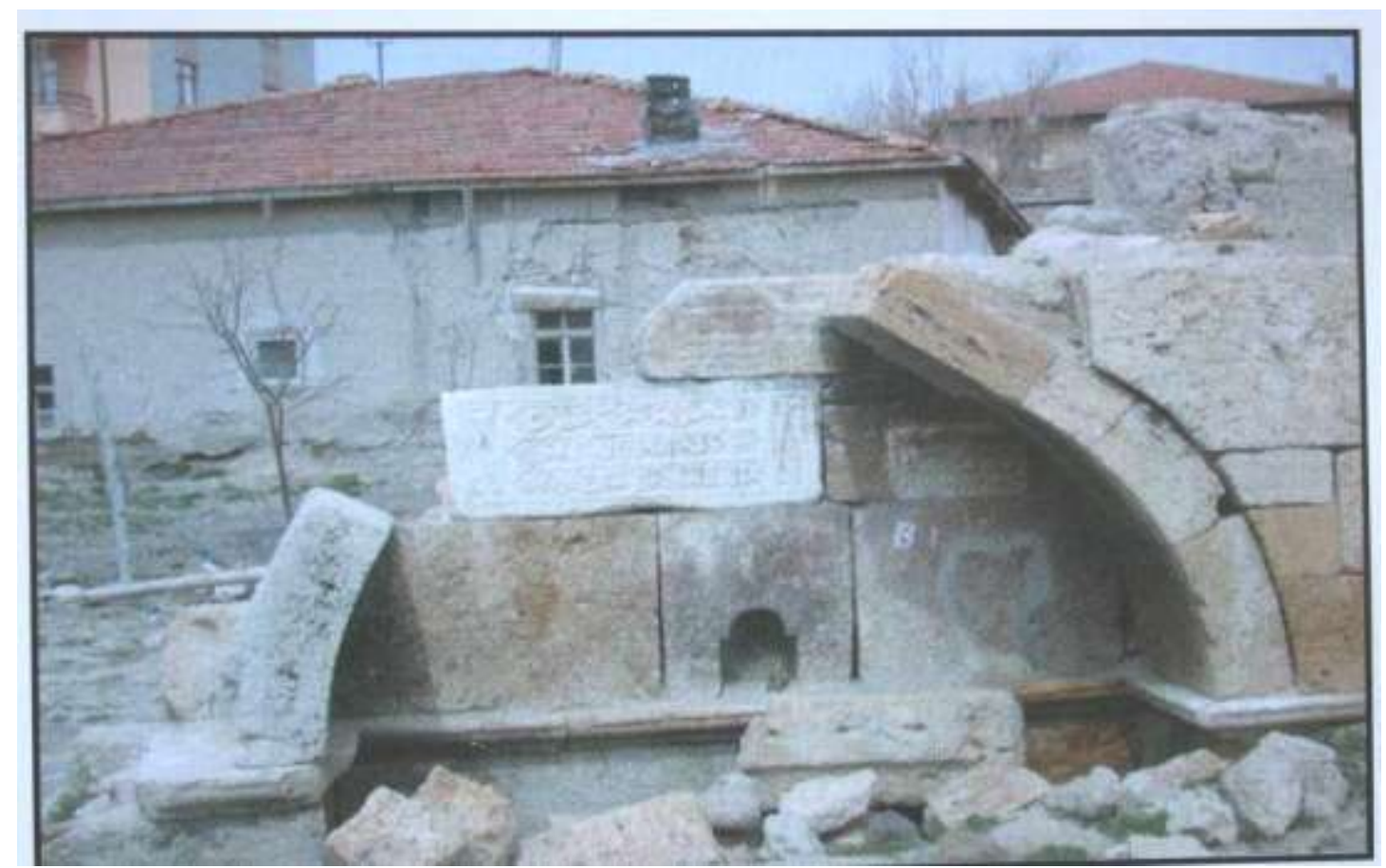

Fotoğraf-9: Ağaların Çeşmesi (Kırşehir Kültür Envanteri'nden)

\footnotetext{
${ }^{2}$ Kırşehir Valiliği tarafından 2006 yılında hazırlanan Kırşehir İ Kültür Envanteri'nin 68. sayfasında çeşmenin kısmen ayakta olduğunu gösteren yukarıdaki fotoğraf yer almaktadır. Ayrıca yine envanterde, çeşme nişi içerisinde üç adet Osmanlıca kitabe olduğu belirtilmektedir. Çeşmenin bulunduğu çevrede yaptığımız arazi çalışması sırasında, çeşmenin tamamen yıkıldığı ve çevresinde herhangi bir kitabenin bulunmadığı görülmüştür. Kırşehir müzesine konu ile ilgili olarak başvurmamız sonucunda da söz konusu kitabelerin müzeye getirilmediği anlaşılmıştır. Ayrıca, çeşme günümüzde tamamen yıkıldığı için, ölçüleri alınıp çizim yapılması da mümkün olmamıştır.
} 


\subsection{Hacı Mustafa Çeşmesi:}

Eser, Kayabaşı Mahallesi'nde Zemine Hatun Camisi'nin kuzeybatı köşesinde bulunmaktadır. Günümüzde, tamamen yıkıımış olan yapının sadece temel bakiyeleri ve kitabeleri sağlam durumdadır. Kalan izlerden mahalle çeşmesi şeklinde düzenlendiği anlaşılmaktadır (Fotoğraf-10).

Sağlam durumda günümüze ulaşan kitabeye göre çeşme, H.1255/M.1839 yılında inşa edilmiştir.

Hacı Mustafa Çeşmesi'nin kalıntıları üstünde iki adet kitabe günümüze ulaşmıştır. Sırt sırta yerleştirilmiş olan kitabelerden doğu taraftaki, çeşmenin inşa kitabesidir (Fotoğraf-11). Batı taraftaki kitabede ise îhlâs Sûresi ve Kelime-i Tevhid yazılıdır (Fotoğraf-12).

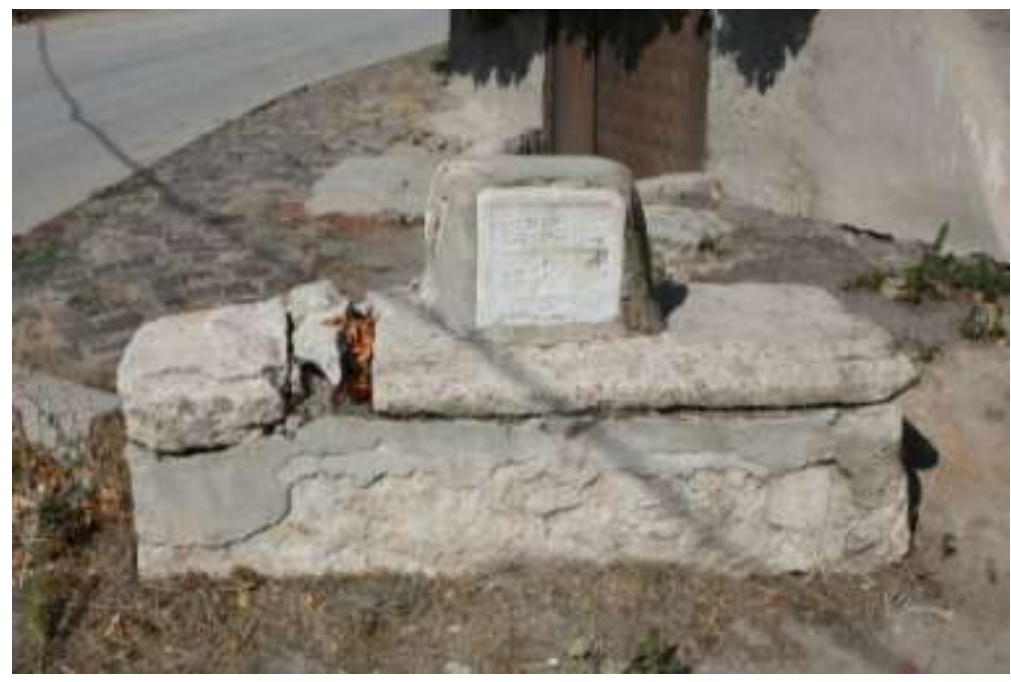

Fotoğraf-10: Hacı Mustafa Çeşmesi

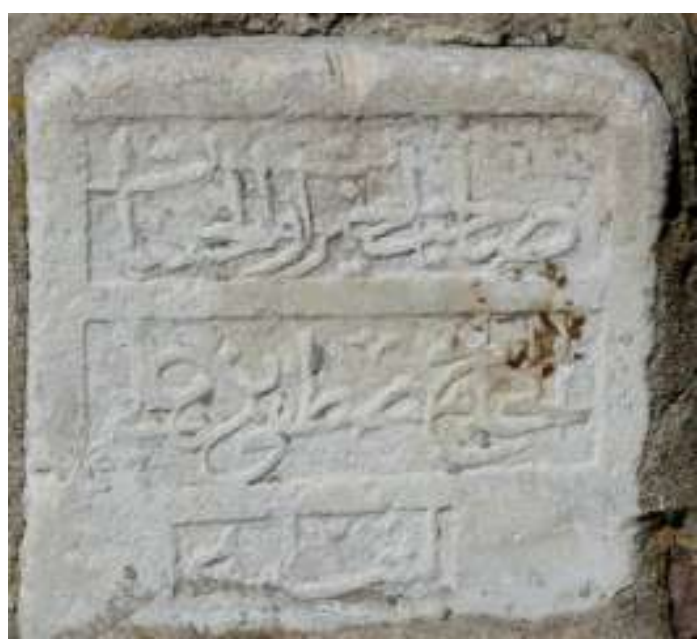

Fotoğraf-11: Hacı Mustafa Çeşmesi

Doğu yüzdeki kitabe

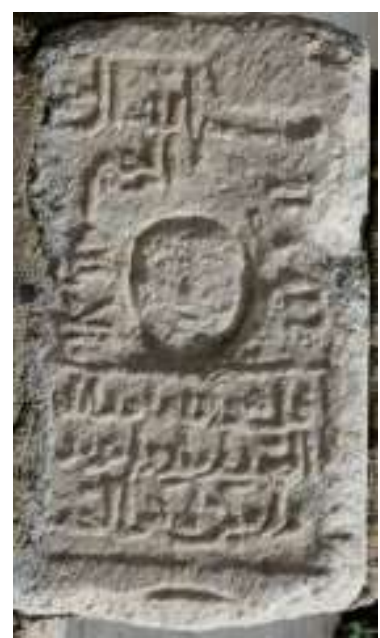

Fotoğraf-12: Hacı Mustafa Çeşmesi

Batı yüzdeki kitabe 


\section{Doğu yüzdeki kitabenin okunuşu:}

Sahib'ül hayrat ve'l hasenat

El-Hac Mustafa bin Ali

Sene 1255

\section{Doğu yüzdeki kitabenin anlamı:}

Hayır ve hasenat sahibi / Ali oğlu Hacı Mustafa / Sene H. 1255 / M. 1839.

\section{Batı yüzdeki kitabenin okunuşu:}

\section{Bismillahirrahmanirrahim}

Lailahe illallah

Kul hüvallâhü ahad Allah

Üs-samed, lem yelid ve lem yûled.

Ve lem yekûn lehû küfüven ehad.

\section{Batı yüzdeki kitabenin anlamı:}

(Ey Muhammed!) De ki: O Allah'tır, bir tektir.

"Allah samettir.(Her şey ona muhtaçtır; $O$, hiçbir şeye muhtaç değildir)

O, doğurmamış ve doğmamıştır.

Hiçbir şey O’nun dengi ve benzeri değildir.

\section{DEĞERLENDIRME}

2.1.Tipoloji: Çeşmeler ile ilgili bugüne kadar yapılan çalışmalarda, araştırmacılar farklı özellikleri dikkate alarak gruplandırma yapmışlardır (Çeşmelerin gruplandırılışı hakkında ayrıntılı bilgi için bkz., Aytöre, 1962: 45-49; Arseven, 1983: 389-390; Eyice, 1993: 277-287; Ödekan, 1992: 281-297; Ödekan, 1994: 488-491; Önge, 1997: 14) Biz bu çalışmada, Ayla Ödekan tarafından yapılan tipolojiyi örnek aldık (Ödekan, 1992: 281-297). Bu tipolojiye göre Kırşehir Çeşmeleri, cephe düzenlemeleri ve bulundukları yere göre gruplandırılmıştır.

2.1.1.Cephe Düzenlemelerine Göre Çeşmeler: Çeşmeler diğer yapı türlerine göre daha küçük boyutlu oldukları için sadece ön cephe olarak adlandırabileceğimiz esas çeşmenin bulunduğu cepheye göre değerlendirilecektir. Çeşmelerin diğer cephelerindeki mimari öğeler, yapı elemanları başlığı altında ele alınmıştır.

Kırşehir'deki çeşmelerin tamamında tek cephe ve tek kemer uygulaması görülmektedir. Günümüze sağlam olarak ulaşan çeşmelerin tamamı, tek kemerli olarak inşa edilmiştir. Tamamen yıkılmış olan Ağaların Çeşmesi'nin de eski fotoğraflarından tek kemerli olduğu anlaşılmaktadır. Günümüze ulaşamayan Hacı Mustafa 
Çeşmesi'nin (M.1839) ise cephe düzeni hakkında bilgiye ulaşamadık. Çeşmelerin cephe düzenlemelerinde uygulanan kemer türleri ise, yuvarlak ve sivri kemerdir.

2.1.1.1.Yuvarlak Kemerli Çeşmeler: Yuvarlak kemerli cephe tasarımı Kırşehir'de dört çeşmede (Ahi Evren Çeşmesi (XIX.Yy.), Tekke Çeşmesi (XIX.Yy.), Süleyman Ağa Çeşmesi (M.1735-36) ve Susuz Çeşme (XIX.yy.)) uygulanmıştır.

Kırşehir dışında, bölgeye yakın yerleşim merkezlerinde Kayseri Güdüllü Çeşmesi (XVI.yy.) (Yörükoğlu, 1987: 132-134), Kayseri-Büyük Bürüngüz Mütevelli Çeşmesi (18.yy. başları) (Denktaş, 1998: 169-170), Kayseri-Talas Esma Hanım Çeşmesi (1887) (Türkmen, 1997: 162), Karaman Kadıbudak Çeşmesi (1551) (Denktaş, 2000a: 3034), Karaman Ali Dede Tartan Çeşmesi (1809) (Denktaş, 2000a: 90-93), Kayseri-Yeşilhisar Çeşmesi (1864) (Denktaş, 2000b: 117-118), Kayseri Çukur Çeşme (Denktaş, 2000b: 129-130), Kayseri-Kemer Köyü Çeşmesi (1902) (Denktaş, 2000b: 130-132) ve Kayseri-Tavlusun Köyü Abdullah Efendi Çeşmesi'nde (1830) (Denktaş, 2000b: 112-114) yuvarlak kemer görülmektedir.

Kırşehir'deki inşa tarihi bilinmeyen yuvarlak kemerli çeşmelerin, benzer örneklerinin ağırlıklı olarak XIX.yy. içinde yapılmış olmasından hareketle, Ahi Evren Çeşmesi, Susuz Çeşme ve Tekke Çeşmesi'ni de XIX.yy.a tarihlendirebiliriz.

2.1.1.2.Sivri Kemerli Çeşmeler: Kırşehir'de günümüze sağlam olarak ulaşan çeşmelerden sadece Şeyh Kızı Hatice Çeşmesi'nde (M.1870) sivri kemer görülmektedir. Şeyh Kızı Hatice Çeşmesi (M.1870) dışında, eski fotoğraflarından (Güçlü, 2006: 68) Ağaların Çeşmesi'nin de sivri kemerli olduğu anlaşılmaktadır.

Anadolu'nun çeşitli yerlerinde, Osmanlı Döneminde inşa edilen ve günümüze ulaşan tek cepheli çeşmelerde en çok sivri kemer uygulanmıştır. Manisa Dokur Çeşmesi (Tarihsiz) (Acun, 1999: 627), Karapınar II. Selim Çeşmesi (1569) (Bildirici, 1994: 257), Kayseri Yazı Camii Çeşmesi (Yörükoğlu, 1987: 97-99), Kayseri-Subaşı Köyü Çeşmesi (1782), (Denktaş, 2000b: 93-95), Kayseri Oduncu Çeşmesi (Yörükoğlu, 1987: 128-131), Karaman Emine Hanım Çeşmesi (1725) (Denktaş, 2000a: 48-50), Karaman-Şıhlar Sokağı Çeşmesi (1852) (Denktaş, 2000a: 71-74) ve Kayseri Kadı Çeşmesi (14.yy.) (Yörükoğlu, 1987: 69-71) sivri kemerli çeşmelere örnek olarak sıralanabilir.

2.1.2.Bulundukları Yere Göre Çeşmeler: Kırşehir'de tespit ettiğimiz çeşmelerin tamamı; (Ağaların Çeşmesi, Ahi Evren Çeşmesi (XIX.yy.), Susuz Çeşme (XIX.yy.), Şeyh Kızı Hatice Çeşmesi (M.1870), Tekke Çeşmesi (XIX.yy.), Süleyman Ağa Çeşmesi (M.1735-36) ve Hacı Mustafa Çeşmesi (M.1839)) herhangi bir yapıya bitişik olmaksızın mahalle çeşmesi şeklinde düzenlenmiştir.

2.2.Yapı Elemanları: Çeşmeler küçük boyutlu yapılar olması sebebiyle, yapı ve cephe elemanları birlikte ele alınmıştır. Kırşehir çeşmelerinde yapı elemanı olarak: duvar, ayak, üst örtü, bardaklıklar, ayna taşları, su yalakları ve dinlenme sekileri değerlendirmeye alınmıştır. Kemerler ise cephe düzenlemesinde ayrıntılı olarak ele alındığı için burada tekrarlanmayacaktır. 
2.2.1.Duvar: Kırşehir'deki çeşmelerin tamamı dört duvardan oluşturulmuş dikdörtgen prizma şeklindedir. Ancak, Tekke Çeşmesi'nin (XIX.yy.) arka cephesi, inşa edildiği arazinin eğiminden dolayı toprakla kaplanmıştır.

2.2.2.Ayaklar: Kırşehir çeşmelerinden, Ahi Evren Çeşmesi (XIX.yy.), Şeyh Kızı Hatice Çeşmesi (M.1870), Tekke Çeşmesi (XIX.yy.) ve Süleyman Ağa Çeşmesi'nin (M.1735-36) nişini örten kemerler, yanlarda yer alan yığma ayaklar üstüne oturur. Eski fotoğraflarından, Ağaların Çeşmesi'nin (XIX.yy.) nişini örten kemerin de ayaklar üstüne oturduğu anlaşılmaktadır. Kemerleri taşıyan bu ayakların tamamı yığma tekniğinde inşa edilmiştir. Ayaklar ortalama, $0.70 \times 0.60 \mathrm{~m}$. eninde ve $0.55 \mathrm{~m}$. ile $0.75 \mathrm{~m}$. yüksekliğindedir. Çeşmelerde yekpare ayak bulunmadığı gibi sütun da kullanılmamıştır. Hacı Mustafa Çeşmesi (M.1839) günümüze sağlam durumda ulaşamadığı ve eski fotoğrafları da bulunmadığı için mimarisi hakkında fazla bilgi sahibi olamıyoruz.

2.2.3.Üst Örtü: Kırşehir'deki çeşmelerden sadece Süleyman Ağa Çeşmesi'nin (M.1735-36) üstü, ön tarafta yuvarlak kemer formunda, arka tarafta ise düz dam şeklinde düzenlenmiştir. Diğer çeşmelerin tamamının üstü düz dam olarak yapılmıştır.

2.2.4.Bardaklıklar: Kırşehir'deki çeşmelerden, Şeyh Kızı Hatice Çeşmesi (M.1870) ve Tekke Çeşmesi'nin (XIX.yy.) çeşme nişi içerisinde bardaklık yer almaktadır. Her iki çeşmenin bardaklığı da düzgün kesme taş malzemeden yapılmıştır. Ağaların Çeşmesi'nin (XIX.yy.) eski fotoğraflarından anlaşıldığı üzere, bu çeşmede de düzgün kesme taştan yapılmış bir bardaklık bulunmaktadır.

2.2.5.Ayna Taşı: Ahi Evren Çeşmesi'nde (XIX.yy.), tek delikli büyük bir blok taş; Şeyh Kızı Hatice Çeşmesi'nde (M.1870), iki delikli yatay dikdörtgen düzgün kesme taş, ayna taşı olarak kullanılmaktadır. Susuz Çeşme'nin (XIX.YY.) nişi, ayna taşının yarısına kadar toprakla dolmuştur, ancak taşın üstündeki delikten ayna taşı olduğu anlaşılmaktadır. Tekke Çeşmesi'nin (XIX.yy.) kitabe panosu, ortasına bir delik açılarak ayna taşı olarak değerlendirilmiştir. Ahi Evren Çeşmesi (XIX.Yy.), Tekke Çeşmesi (XIX.yy.) ve Süleyman Ağa Çeşmesi'nin (M.173536) ayna taşlarında tek delik, Şeyh Kızı Hatice Çeşmesi'nin (M.1870) ayna taşında ise çift delik bulunmaktadır. Ağaların Çeşmesi ve Hacı Mustafa Çeşmesi (M.1839) tamamen yıkıldığı için ayna taşı bulunup bulunmadığı hakkında herhangi bir bilgiye ulaşamadık.

2.2.6.Su Yalakları: Suyun insanların üstüne sıçramaması ve biriktirilerek hayvanlar için de kullanılabilmesi düşüncesiyle çeşmelerde suyun aktığı yere derin yalaklar yapılır (Denktaş, 2000a: 199-200). Kırşehir çeşmelerinden günümüzde hâlâ kullanılmakta olan, Ahi Evren Çeşmesi (XIX.yy.), Şeyh Kızı Hatice Çeşmesi (M.1870) ve Tekke Çeşmesi'nde (XIX.yy.) su yalağı bulunmaktadır. Süleyman Ağa Çeşmesi'nin (M.1735-36) su yalağı ise toprakla kapanmıştır. Susuz Çeşme'nin (XIX.yy.) nişi, ayna taşının delik hizasına kadar toprak altında kaldığı için su yalağı olup olmadığını bilmiyoruz. Ağaların Çeşmesi ve Hacı Mustafa Çeşmesi (M.1839) günümüze sağlam olarak ulaşmadığı için su yalakları hakkında bilgi sahibi değiliz.

2.2.7.Dinlenme Sekileri: Su doldurmaya ve içmeye gelenlerin dinlenebilmeleri için, çeşme nişi içerisine yapılan dinlenme sekileri büyük oranda ortadan kalkmıştır. Kırşehir'deki çeşmelerden sadece Ahi Evren Çeşmesi'nde 
(XIX.Yy.) dinlenme sekisi mevcuttur. Diğer çeşmelerin aslî hallerinde dinlenme sekisi varsa bile günümüze ulaşmamıştır.

2.3.Kitabe: Günümüze ulaşan çeşmelerden, Şeyh Kızı Hatice Çeşmesi (M.1870), Tekke Çeşmesi (XIX.yy.) ve Süleyman Ağa Çeşmesi'nde (M.1735-36) kitabe bulunmaktadır. 2006 yılında hazırlanan envanterde, Ağaların Çeşmesi'nde, üç adet Osmanlıca kitabe olduğu belirtilmektedir (Güçlü, 2006: 68). Tekke Çeşmesi'nde (XIX.yy.), kitabenin ortası delinerek ayna taşı olarak kullanılması, bu kitabenin başka bir yapıdan getirildiğini düşündürmektedir.

Hacı Mustafa Çeşmesi'nin (M.1839) kalıntıları üstünde iki adet kitabe günümüze ulaşmıştır. Sırt sırta yerleştirilmiş olan kitabelerden doğu taraftaki, çeşmenin inşa kitabesidir. Batı taraftaki kitabede ise İhlas Sûresi ve Kelime-i Tevhid yazılıdır. Doğu taraftaki kitabenin çeşmeye ait olduğu anlaşılmaktadır. Ancak batı taraftaki kitabenin, bu çeşmeye mi ait olduğu yoksa başka bir yapıdan mı getirildiği hususunda herhangi bir bilgiye ulaşamadık.

2.4.Malzeme: Kırşehir'deki çeşmelerin inşasında: moloz, kaba yonu ve düzgün kesme taşla birlikte mermer ve devşirme malzemenin de kullanıldığı görülmektedir. Şeyh Kızı Hatice Çeşmesi (M.1870), sarı renkli düzgün kesme taşla yapılmıştır, ancak kitabesi mermerdir. Süleyman Ağa Çeşmesi (M.1735-36) çimento harcı ile birbirine bağlanmış kaba yonu taşlarla inşa edilmiştir. Kitabesi ise mermer malzeme üstüne işlenmiştir. Susuz Çeşme (XIX.yy.), kaba yonu taşlarla; Tekke Çeşmesi (XIX.yy.) ise düzgün kesme taşlarla yapılmıştır. Ahi Evren Çeşmesi'nde (XIX.yy.), moloz, kaba yonu ve kesme taşla birlikte devşirme malzeme de kullanılmıştır.

Hacı Mustafa Çeşmesi (M.1839) ve Ağaların Çeşmesi ise bugün için mevcut değildir. Ancak, Ağaların Çeşmesi'nin eski fotoğraflarından, düzgün kesme taşlarla inşa edildiğini ve mermer kitabeye sahip olduğunu biliyoruz. Hacı Mustafa Çeşmesi'nin (M.1839) ise sadece mermer kitabeleri günümüze ulaşmıştır.

2.5.Süsleme: Kırşehir'de tespit edilen çeşmeler, oldukça sade düzenlemelere sahiptir. Çeşmelerden sadece Hacı Mustafa Çeşmesi (M.1839) ve Süleyman Ağa Çeşmesi'nin (M.1735-36) kitabelerinde süslemeye yer verilmiştir. Günümüzde tamamen yıkılmış olan Hacı Mustafa Çeşmesi'nin (M.1839) batı taraftaki kitabesinde besmeleden sonra, iki tarafında Kelime-i Tevhid yazılı insan yüzü bulunmaktadır (Türk Sanatında görülen insan figürlü süslemelerle ilgili ayrıntılı bilgi için bkz., Öney, 1967: 143-167; Yalçınkaya, 2007). Süleyman Ağa Çeşmesi’nin (M.1735-36), üç sütun, dört satır halinde düzenlenmiş olan kitabe panosunda, orta sütunun en alt sırasındaki dikdörtgen alan içerisinde, çiçeklerin işlendiği bitkisel kompozisyon görülmektedir. İstanbul-Azapkapı Saliha Sultan Çeşmesi'nde (1732-35) benzer süslemeler görülmektedir (Barışta, 1995).

\section{SONUÇ}

Çalışmamız sonucunda, Kırşehir'de beşi ayakta ikisi yıkılmış olmak üzere tamamı XVIII. ve XIX. yüzyıllara ait yedi adet tarihi çeşme tespit edilmiştir. Günümüze sağlam olarak ulaşan çeşmelerden, Şeyh Kızı Hatice Çeşmesi 
(M.1870), Ahi Evren Çeşmesi (XIX.yy.) ve Tekke Çeşmesi (XIX.yy.) halen kullanılmaktadır. Süleyman Ağa Çeşmesi (M.1735-36) ve Susuz Çeşme (XIX.yy.) ise kullanılmadığı için oldukça bakımsız durumdalar.

Kırşehir'deki tarihi çeşmeler mimari özellikler açısından Türk su mimarisinin önemli örneklerini oluşturmaktadır. Anadolu'nun farklı bölgelerinde görülen benzer örnekler ise Kırşehir Çeşmeleri'nin bütün içindeki yerini görmemizi sağlamaktadır.

Günümüzde her eve şebeke sularının gelmesiyle birlikte önemini yitiren mahalle çeşmeleri hızla yok olma tehlikesiyle karşı karşıyadır. Ancak çeşmeler, sadece su içilen ya da su alınan bir mimari kuruluş değil, taşıdıkları sularla hayat kaynağımız olduğu gibi, çevrelerinde oluşan sosyal hayatla da, kültürümüzün en önemli öğelerinden biridir. Özellikle mahallelerde, kadınlar, kızlar ve çocuklarımız için önemli sosyalleşme alanlarından birini oluşturan, mahalle hayatının vazgeçilmezlerinden çeşmelerimiz, çarpık kentleşmenin ve bilinçsiz yapılaşmanın kurbanı olmaktadır. Farkında olmadan gözlerimizin önünden birer birer kaybolup giden, sadece taş duvarlar değil, aynı zamanda kültürümüzün temel taşlarıdır.

Sonuç olarak; ilgililerin tarihi çeşmelerimizin en azından bugün ayakta olanları onarmaları ve asli fonksiyonlarına kavuşturmaları gerekmektedir. Aksi takdirde gelecek nesiller kültürümüzün bu nadide eserlerini ancak kitaplarda görebileceklerdir. Unutulmamalıdır ki, "su” canlılar için olduğu kadar çeşmeler içinde hayat kaynağıdır.

\section{KAYNAKÇA}

ACUN, H. (1999), Manisa'da Türk Devri Yapıları, Ankara, Türk Tarih Kurumu.

ARSEVEN, C. E. (1983), “Çeşme”, Sanat Ansiklopedisi, Cilt 1, İstanbul, s.388-390.

AYTÖRE, A. (1962), "Türklerde Su Mimarisi”, I. Milletlerarası Türk Sanatları Kongresi, Tebliğler, Ankara, s.4549.

BARıŞTA, H. Ö. (1995), İstanbul Çeşmeleri, Azapkapı Saliha Sultan Çeşmesi, Ankara, T.C. Kültür Bakanlığı.

BASıNOĞLU, E. (1981), Çeşitli Yönleriyle Kırşehir, Kırşehir, Filiz Yayınları.

BildiRici, M. (1994), Tarihi Su Yapıları, Ankara.

DENKTAŞ, M. (1998), “Kayseri-Büyük Bürüngüz Köyü’ndeki Türk Anıtları”, Vakıflar Dergisi, S.27, Ankara, s.161190.

DENKTAŞ, M. (2000a), Karaman Çeşmeleri, Kayseri.

DENKTAŞ, M. (2000b), Kayseri'deki Tarihi Su Yapıları, Kayseri.

EYICE, S. (1993), “Çeşme”, İslam Ansiklopedisi, Cilt 8, İstanbul, s.277-287. 
GÜÇLÜ, A. (2006), Kırşehir il Kültür Envanteri, Kırşehir, T.C. Kırşehir Valiliği.

GÜNDÜZ, A. (2009), Kırşehir'de Vakıflar ve Vakfiyeler (H.670-1335 / M. 1271-1919), Kırşehir, T.C. Kırşehir Valiliği.

ÖDEKAN, A. (1992), “Kentiçi Çeşme Tasarımında Tipolojik Çözümleme”, Semavi Eyice'ye Armağan, İstanbul Yazıları, İstanbul, s.281-297.

ÖDEKAN, A. (1994), “Çeşmeler”, Dünden Bugüne İstanbul Ansiklopedisi, İstanbul, s.488-491.

ÖNEY, G. (1967), “Niğde Hüdavent Hatun Türbesi Figürlü Kabartmaları”, Belleten, Cilt 31, S.122, Nisan, s.143167.

ÖNGE, Y. (1997), Türk Mimarisinde Selçuklu ve Osmanlı Dönemlerinde Su Yapıları, Ankara.

ŞAHIN, I. (2001), “Kırşehir”, (DiA), Cilt 25, İstanbul, Türkiye Diyanet Vakfı, s.481-485.

TÜRKMEN, K. (1997), “Talas'ta Türk Devri Yapıları”, Vakıflar Dergisi, S. 26, Ankara, s.153-192.

ÜLGEN, A. S. (1942), “Kırşehir'de Türk Eserleri”, Vakıflar Dergisi, S. 2, Ankara, s.253-287.

YALÇINKAYA, A. (2007), Anadolu Türk Mimarisi'nde 12-14. Yüzyıllar Arasına Tarihlenen Cami, Medrese, Şifahane ve Türbe Yapılarındaki Taş Üzerine Yapılmış İnsan Figürlü Bezemeleri, (Anadolu Üniversitesi Sosyal Bilimler Enstitüsü Sanat Tarihi Anabilim Dalı Yayınlanmamış Yüksek Lisans Tezi), Eskişehir.

YILMAZ, A. (2006), Küçük Asya'nın Kır-şehri, Kırşehir, Kırşehir Belediyesi. 